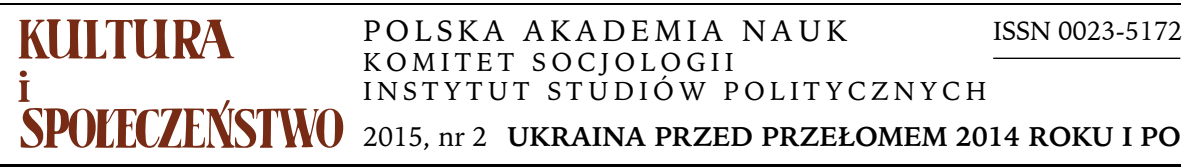

TADEUSZ ANDRZEJ OLSZAŃSKI

Ośrodek Studiów Wschodnich

\title{
CO UJAWNIŁA REWOLUCJA GODNOŚCI
}

Chciałbym tu zwrócić uwagę na zjawiska opisane dotychczas w niewielkim stopniu. Rewolucja Godności 2014 roku (początkowo zwana Euromajdanem) nie tylko przyniosła rzeczywiście rewolucyjne zmiany polityczne i społeczne (te drugie w chwili pisania tego tekstu trudno jeszcze ocenić), ale ujawniła konsekwencje procesów zachodzących już wcześniej. Nie jest to opracowanie naukowe, lecz esej w klasycznym rozumieniu słowa: próba, zarys problemu. Nie prowadziłem badań socjologicznych ani demograficznych, nie studiowałem źródeł historycznych. Opieram się na wiedzy zgromadzonej podczas zajmowania się analizą rozwoju sytuacji politycznej i społecznej na Ukrainie, pochodzącej z rozproszonych źródeł medialnych, eseistyki, rozmów o charakterze służbowym i prywatnym itd.

\section{PODZIAEY UKRAINY}

Ukraina jest krajem ogromnie zróżnicowanym wewnętrznie. To truizm. Ale podziały te są mniejsze, niż się potocznie sądzi (i niż rzeczywiście były kilkadziesiąt lat temu), ich natura jest też nieco inna, niż głosi stereotyp „wschodu i zachodu". Znacząco osłabły one po roku 1945, kiedy to całe terytorium Ukrainy stało się jednolitą przestrzenią migracyjną (do roku 1991 było także elementem sowieckiej przestrzeni migracyjnej). W konsekwencji wielu mieszkańców przeważnie rolniczych obwodów zachodnich przenosiło się do miast obwodów wschodnich i południowych (a także do Kijowa), ale też wielu mieszkańców tych ostatnich terenów przenosiło się do miast obwodów zachodnich, wylud- 
nionych po drugiej wojnie światowej oraz nowych ośrodków przemysłowych na zachodzie kraju. Ukraina była też, jeśli można tak powiedzieć, jednolitą przestrzenią matrymonialną: liczba paropokoleniowych już rodzin „międzyregionalnych" dziś idzie chyba w miliony.

Sprzyjało to „wyrównywaniu” świadomości etniczno-narodowej. Z jednej strony wychodźcy z obwodów zachodnich byli liczni także wśród elit uniwersyteckich Dniepropietrowska i Doniecka, z drugiej w centrum Lwowa wciąż (choć już niedługo) przeważają powojenni osiedleńcy z Rosji i wschodniej Ukrainy. Także we Lwowie nie brak, jak to ujął jeden z moich korespondentów, „entuzjastów Putina i «russkogo mira» oraz janukowyczowskich konformistów". Z drugiej strony w ochotniczych batalionach Gwardii Narodowej, walczących z donieckimi rebeliantami i wspierającymi ich Rosjanami, bardzo liczni są mieszkańcy obwodów wschodnich, czasem z „zachodnimi” korzeniami, częściej nie. Zdaniem wielu obserwatorów większość ochotników jest rosyjskojęzyczna. Na przykład przywódca radykalnie nacjonalistycznej organizacji „Prawy Sektor”, Dmytro Jarosz, urodził się w 1971 roku w Dnieprodzierżyńsku (obwód dniepropietrowski); jest grekokatolikiem, więc co najmniej część jego przodków pochodzi z Galicji Wschodniej. Inny z dowódców tych batalionów, Semen Semenczenko, jest etnicznym Rosjaninem pochodzącym z Krymu, jego obecne nazwisko było początkowo pseudonimem: „z domu” nazywał się Konstantyn Griszin.

Niezależnie od tego mitem jest dychotomiczny podział na „Ukrainę” i „Noworosję", ostatnio wznowiony przez propagandę rosyjską. Nigdy nie istniała Noworosja jako w miarę jednolity etnicznie, politycznie i świadomościowo region, obejmujący ziemie od Odessy po Charków ${ }^{1}$. Charków, do dziś uważający się za "pierwszą stolicę” Ukrainy ${ }^{2}$, i Donieck, „wszechzwiązkowa węglarka”, Dniepropietrowsk, niegdyś jedno z centrów sowieckiego przemysłu rakietowego, oraz Odessa, także dziś jeden z głównych portów rosyjskiego handlu morskiego - to różne „światy”, metropolie regionalne o własnej, silnej tożsamości, stolice regionów o bardzo różnej historii. I bez jakiejkolwiek tożsamości wspólnej. Jedyne co je łączy, to uczestnictwo w jednej przestrzeni prawnej i tradycji państwowo-narodowej.

\section{URODZENI OBYWATELE}

Według najnowszych danych Ukraina ma 45,4 mln mieszkańców, z czego około $8 \mathrm{mln}$ (17\%) liczy od 18 do 30 lat $^{3}$. Wyodrębniłem tę kategorię, nie

${ }^{1} \mathrm{~W}$ latach $1764-1783$ i ponownie 1796-1802 istniała gubernia noworosyjska obejmująca ziemie od dolnego Dniepru po Ługańsk, a po 1796 roku także ziemie między dolnym Dnieprem a Morzem Azowskim oraz Krym. Jej centrum był Jekaterynosław (obecny Dniepropietrowsk). Charków, stolica Ukrainy Słobodzkiej (Słobożańszczyzny), nigdy do niej nie należał.

2 Charków w latach 1919-1934 był stolicą Ukraińskiej SRS.

${ }^{3}$ Dane szacunkowe na podstawie dostępnych statystyk urodzeń roczników 1984-1996. Są one nieco zawyżone, gdyż nie uwzględniają zgonów ani emigracji. 
mieszczącą się $\mathrm{w}$ przyjętym schemacie podziału na osoby w wieku przedprodukcyjnym, produkcyjnym i poprodukcyjnym, by ujawnić grupę, którą nazywam tu „urodzonymi obywatelami”: tych, którzy rozpoczęli edukację szkolną w niepodległym państwie ukraińskim, dla których Ukraina jest jedyną ojczyzną, jaką znają ${ }^{4}$. Być może można doliczyć do niej kilka wcześniejszych roczników, które w sowieckiej szkole spędziły pierwsze lata. Ich liczebność w najbliższych latach będzie rosła o około 350-400 tys. rocznie, a podział na ukształtowanych w państwie sowieckim i ukraińskim nabiera coraz większego znaczenia. Jedną z ważniejszych różnic między Majdanami z lat 2004 i 2014 jest to, że na tym pierwszym przeważali jeszcze „absolwenci” Związku Sowieckiego, na drugim — już „urodzeni obywatele”, dziesięć lat wcześniej zbyt nieliczni i zbyt młodzi. „Od czego zaczyna się ojczyzna” pytał sowiecki poeta ${ }^{5}$. I odpowiadał: „Z obrazka w twym elementarzu". Tak naprawdę zaczyna się ona od mapy i herbu w szkolnej klasie. To one, a także język nauczania i struktura przedmiotów, szkolne obyczaje i ceremoniały osadzają uczniów w ojczyźnie szerszej niż ta, o której pojęcie może mieć siedmiolatek wychodzący z domu. A jeżeli na przykład w Polsce zmiany symboliki po obaleniu ustroju komunistycznego miały kosmetyczny charakter, a kształt ojczyzny pozostał ten sam, to na Ukrainie zmiany były wręcz diametralne. Ojczyzną przestała być „szyroka strana moja radnaja [...] od Moskwy do samych, do okrain" " $z$ „kartograficznym" centrum gdzieś nad Bajkałem, stał się nią zaś kraj „wid Sianu do Donu" ", już na tym poziomie wpisany w Europę.

Typowe mapy Związku Sowieckiego (współcześnie: Federacji Rosyjskiej) były budowane wokół południka $100^{\circ}$ długości geograficznej wschodniej, to jest ten lub zbliżony południk był na mapie wyobrażony w postaci linii pionowej. Wynikało to ze względów praktycznych (ten południk dzielił państwo na mniej więcej równie rozciągnięte ze wschodu na zachód części), ale umieszczało ZSRS przede wszystkim w Azji, a republiki europejskie - na peryferiach; w niektórych odwzorowaniach kartograficznych oś równoleżnikowa Ukrainy (a także Polski) zbliżała się do linii pionowej względem ramki

\footnotetext{
4 Jeden $z$ nielicznych autorów zwracających uwagę na omawianą tu przemianę pisze o „pokoleniu niepodległości" (roczniki 1985-1995). Autor ten zwraca też uwagę na pokrewieństwa Euromajdanu z ruchem Occupy i „rewolucją prekariatu”; wątki godne uwagi, ale wykraczające poza ramy tego tekstu. Zob. Hrycak 2014.

5 Tak naprawdę nie poeta, lecz tekściarz średniej klasy Michaił Matusowskij. Jednak cytowana tu piosenka filmowa $Z$ czego naczinajetsia Rodina z 1968 roku zyskała wielką popularność i została włączona do nauczania szkolnego, dlatego też pozwoliłem sobie tu ją przywołać.

6 „Rozległy jest mój kraj ojczysty [...] od Moskwy aż do najdalszych kresów” (tłumaczenie własne). Fragment Pieśni o Ojczyźnie Wasilija Liebiediew-Kumacza z 1936 roku, jednej z najpopularniejszych sowieckich pieśni masowych, powszechnie znanej do końca istnienia ZSRS.

7 Od Sanu do Donu. Fragment wiersza Pawła Czubynskiego z 1862 roku, później hymnu państwowego Ukrainy. Druga strofa, z której pochodzi cytat, nie jest uznawana za część hymnu i nie wykonuje się jej podczas uroczystości państwowych.
} 
mapy. Na typowej mapie Ukrainy centralnym („pionowym”) jest południk $30^{\circ}$ długości geograficznej wschodniej, przebiegający nieco na zachód od Kijowa.

Wszyscy uczniowie poznawali teraz język ukraiński, także w szkołach z rosyjskim językiem wykładowym (za czasów sowieckich nauczano go tylko w części szkół). Dzięki temu stawał się językiem Ojczyzny, choćby językiem ojczystym (przez co w krajach postsowieckich rozumie się na ogół język używany $\mathrm{w}$ domu) pozostawał rosyjski. Także w środowiskach, w których budziło to zdecydowany sprzeciw, punkt odniesienia był już inny niż przed 1991 rokiem.

Zmieniło się też pojęcie geografii, historii i literatury ojczystej. Dotychczas była nią geografia i historia ZSRS, ta druga skupiona wokół dziejów Rosji, oraz literatura rosyjska z niewielkimi koncesjami ma rzecz pisarzy ukraińskich i innych — o ile, rzecz jasna, dawali oni się wpisać w sowiecką narrację „literatury w służbie postępu społecznego" (w ten sposób dała się wpisać między innymi twórczość Tarasa Szewczenki). Historii Ukrainy nauczano w ramach historii ZSRS (istniał krótki podręcznik skupiony na czasach sowieckich), jednak na jej omawianie $z$ reguły nie starczało czasu; pewne elementy nauczyciele mogli przemycać na lekcjach krajoznawstwa i „godzinach wychowawczych" 8 . Teraz historia Ukrainy i jej literatura zajęły miejsce centralne.

Rośnie zatem pokolenie, dla którego państwo ukraińskie jest rzeczywistością zastaną, oczywistym punktem odniesienia. Także dla tych, którzy go nie akceptują, którzy pragną żyć w Rosji (lub przynajmniej „po rosyjsku”). Sowiecka, „miękka” ukraińskość/małorosyjskość nie jest już możliwa. To jedno ze źródeł gwałtownego sprzeciwu części mieszkańców wschodu i południa Ukrainy wobec przemian wiązanych z Rewolucją Godności. I do tego procesu, a nie do rzekomego narzucania posługiwania się $\mathrm{w}$ życiu codziennym językiem ukraińskim, odnosi się zarzut „przymusowej ukrainizacji”: chodzi nie o nowy język, lecz nową narrację tożsamości, nowy punkt odniesienia.

Zarówno przedrewolucyjne państwo, jak i społeczeństwo rosyjskie uznawały odrębność Wielkorusów, Małorusów i Białorusów (kategorie te uwzględniono na przykład w spisie powszechnym z 1897 r.), ale uważano ten podział za wewnętrzny w ramach jednego narodu rosyjskiego (rozumianego nieco inaczej niż narody Europy Środkowej). Dlatego małorosyjskość była tolerowana, a nawet hołubiona, natomiast tworzenie kultury wysokiej w języku ukraińskim, nie mówiąc o rozwijaniu idei odrębności Ukraińców od Rosjan zwalczane. Stan ten utrzymał się w czasach sowieckich, choć wówczas zrezygnowano z głoszenia „trójjedyności” narodu rosyjskiego i zarzucono pojęcie

\footnotetext{
8 Informacje dotyczące przełomu lat siedemdziesiątych i osiemdziesiątych.

${ }^{9} \mathrm{~W}$ Rosji, na Ukrainie, a zapewne i w innych krajach postsowieckich powszechnie nadużywa się terminologii biologicznej/genetycznej do opisu zjawisk społecznych w celu nadania im cech biologicznych, a więc „naturalnych”. Stąd na przykład często spotykany na Ukrainie pogląd, że Rosjanie nie są Słowianami, lecz „genetycznymi” Ugrofinami itd.
} 
Małorusów i małorosyjskości. Pozwalało to być w sposób harmonijny zarazem patriotą imperialnym (carskim lub sowieckim) i małorosyjskim (w czasach sowieckim - ukraińskim). Pogląd o fundamentalnej, niekiedy wręcz „genetycznej” 9 jedności Słowian Wschodnich (a nawet wszystkich Słowian) także dziś jest rozpowszechniony zarówno w Rosji, jak i wśród ukraińskich Rosjan.

Zmiany, o których mówimy, doprowadziły do zniwelowania w pewnym stopniu podziałów językowych. Dotychczasowy podział na regiony w zasadzie ukraińskojęzyczne (wieś, miasta obwodów zachodnich), surżykojęzyczne ${ }^{10}$ (miasta centrum kraju łącznie z Kijowem) i rosyjskojęzyczne (miasta pozostałej części kraju, częściowo wieś południa kraju oraz Krym) coraz wyraźniej traci jednoznaczność i właśnie terytorialność. Wszyscy młodzi znają ukraiński przynajmniej na poziomie elementarnym, ale też wszyscy są pod wpływem kultury masowej, ta zaś na Ukrainie istnieje niemal wyłącznie $\mathrm{w}$ rosyjskiej szacie językowej. W efekcie rosyjski jest dziś w życiu codziennym zachodnioukraińskich miast obecny znacznie szerzej niż ćwierć wieku temu, ale w centrum, a nawet na wschodzie, coraz częściej można spotkać ignorowanie tego języka, zwłaszcza wobec cudzoziemców ${ }^{11}$.

\section{OTWARCI NA PRZEMOC}

Do jesieni 2013 roku organizatorzy protestów społecznych na Ukrainie uznawali pokojowy ich charakter za wartość nadrzędną, przeceniali groźbę rozlewu krwi, gdy zaś dochodziło do starć z milicją - wygaszali akcję (wyraźne było to zwłaszcza w marcu 2001 roku, podczas zakończenia akcji „Ukraina bez Kuczmy"). Niewykluczone, że odpowiedzialni za pogrom Euromajdanu nocą z 29 na 30 listopada 2013 r. liczyli na podobny efekt, tym bardziej że studencki protest już się wypalał. Majdan nie miał jednak przywódców zdolnych go „rozwiązać” (czołowi politycy ukraińskiej opozycji cały czas dążyli do ograniczenia skali protestów, a przywódcy Euromajdanu nie kierowali protestami, lecz poddawali się ich dynamice).

Ku zaskoczeniu większości obserwatorów brutalność milicji wywołała nie strach, lecz wściekłość. Dwa dni później podczas wielkiej manifestacji ponownie zajęto Majdan Niepodległości i kilka gmachów publicznych, a paramilitarne bojówki usiłowały zdobyć siedzibę prezydenta (nawet jeśli w tym ostatnim był element prowokacji, działanie prowokatorów było możliwe dzięki temu, że na

10 Surżyk to nie tyle dialekt czy gwara, ile sposób posługiwania się elementami języka ukraińskiego i rosyjskiego bez uchwytnych regul, powszechny wśród mieszkańców miast i miasteczek centralnej Ukrainy (zob. Bracki 2009).

11 Co jest $\mathrm{w}$ pewnej mierze reakcją na rosyjską agresję z 2014 roku, może więc okazać się fenomenem przejściowym. Jego podstawą jest jednak znacznie szersza niż dwadzieścia, a nawet dziesięć lat temu znajomość ukraińskiego. 
ulice spontaniczne wyszły dziesiątki tysięcy ludzi). Inaczej niż w 2004 roku Samoobrona Majdanu stała się formacją zdolną do konfrontacji z milicją, a sam Majdan - twierdzą. Kolejne akcje władz spotykały się ze stanowczym oporem, który dwukrotnie przeszedł $\mathrm{w}$ walki powstańcze w centrum Kijowa. Podobne działania, choć na znacznie mniejszą skalę, miały miejsce w wielu innych miastach.

W ten sposób objawiła się nowego rodzaju odwaga Ukraińców: gotowość do oparcia się przemocy i odpowiedzi przemocą na przemoc - do narażania własnego życia i sięgania po życie cudze. A społeczeństwo, przez dziesięciolecia powtarzające jak mantrę "byle by nie było wojny" 12 , zareagowało nie tylko solidarnością z walczącymi, ale i dumą z ich walki. Tę zmianę postawy ugruntowała późniejsza wojna, w której formacje ochotnicze oraz rozproszona, społeczna pomoc dla walczących odegrały wielką rolę.

Za gotowością do walki, do ponoszenia ofiar nie idzie jednak skłonność do dyscypliny, do posłuszeństwa rozkazom. Nawet w krytycznych dniach walk ulicznych w Kijowie po stronie Majdanu nie było jednego ośrodka dowodzenia, poszczególne formacje działały na własną rękę, koordynując "poziomo” swe akcje lub nie. Podobnie było w pierwszej fazie działań wojennych. Czasem przynosiło to skutki korzystne, czasem - fatalne. Władzom Ukrainy nie od razu (i wciąż nie do końca) udało się włączyć formacje ochotnicze w struktury sił zbrojnych.

Warto przypomnieć, że lu tow e porozumienie zostało zerwane w spo-
sób cokolwiek przypominający liberum veto lub nieprzychylne opisy literackie
Koła Siczowego. 21 lutego po południu przywódcy opozycji parlamentarnej
zawarli z prezydentem Janukowyczem porozumienie, przewidujące między
innymi przedterminowe wybory prezydenckie jesienią 2014 roku. Gdy w go-
dzinach wieczornych przedstawiano jego treść Majdanowi (wiecowi liczącego
w tym momencie co najmniej 100 tys. uczestników), przez ochronę przedarł
się dowódca jednej z sotni Samoobrony Majdanu, nikomu wcześniej nieznany
Wołodymyr Parasiuk, wyjął mikrofon z rak Witalija Kliczki (ten, wyższy o pół-
torej głowy, był tak zdumiony, że nie zareagował w żaden sposób) i wykrzyczał,
że Majdan nie chce żadnego kompromisu, a Janukowycz ma zrezygnować do
rana, bo inaczej „pójdziemy po niego”. Tłum zgodnym krzykiem „ratyfikował”
to żądanie, Janukowycz nocą uciekł z Kijowa, a wizerunek polityczny Kliczki
legł w gruzach.

Tę zmianę można różnie interpretować, wydaje się jednak, że decydująca jest przemiana pokoleniowa. Dla starszych pokoleń mieszkańców Ukrainy cię-

12 Popularna czastuszka, powstała prawdopodobnie w latach sześćdziesiątych głosiła: „Gwiazdka spadła prosto z nieba / Prosto w spodnie kochanemu; / Niechby wszystko tam spaliła / Byle wojny by nie było" (tłumaczenie własne). Jeden z ukraińskich publicystów w połowie 2014 roku uznał te słowa za realną „ukraińską ideę narodową”, której kształt, a zwłaszcza mniemany brak, jest stałym tematem ukraińskich dyskusji (Jabłonowskij 2014). 
żar strat $z$ lat trzydziestych i czterdziestych to wciąż dziedzictwo odczuwane bezpośrednio (nawet jeśli dotyczyło rodziców). Dla młodszych to już tylko „książkowa” historia, nawet jeśli dobrze znana i głęboko przeżywana. Młodzi są też wolni od wpływu sowieckiej propagandy, krzewiącej jednocześnie strach przed wojną i gotowość do udziału w niej. Wydaje się też, że ta gotowość młodszych pokoleń do przemocy nie jest zjawiskiem wyłącznie ukraińskim, a wśród jego przyczyn są przemiany społeczne zachodzące w całej Europie.

Ukraiński anarchodemokratyzm, tak wyraźny podczas Rewolucji Godności, jest zakorzeniony w narodowej tradycji, stale aktualizowanej przez starą i nową literaturę historyczną. Wzmacniają go też wpływy współczesnej kultury, krzewiącej indywidualizm w dwu formach: jako postawę liberalną, sprzeciwiającą się kolektywizmowi (autorytaryzmowi, totalitaryzmowi) oraz jako postawę konsumpcjonistyczną, zgodnie z którą każdy powinien „być sobą”, to jest dbać tylko o siebie ${ }^{13}$.

Przebieg czynnej fazy Rewolucji Godności ujawnił też rozmiary i znaczenie „obywatelskich” form szkolenia obronnego. Wśród manifestantów byli ludzie $z$ dobrym przeszkoleniem $\mathrm{w}$ zakresie walki wręcz, często $\mathrm{z}$ wyposażeniem niewiele ustępującym milicyjnemu. Byli to nie tylko niezbyt liczni weterani milicji i sił zbrojnych oraz "polityczni” bojówkarze, ale też członkowie grup rekonstrukcji historycznej, bractw rycerskich i klubów larpowych ${ }^{14}$ oraz różnorodnych szkół walki, wreszcie tzw. ultras ${ }^{15}$. Odważni, zdolni i skłonni do współdziałania (choć tylko we własnym kręgu), rzadko poddający się panice, poszukujący niekonwencjonalnych rozwiązań.

\section{UKRAIŃCY I IMIGRANCI}

Wśród ludności Ukrainy można wyróżnić dwie wielkie grupy: jej rdzennych mieszkańców (bez względu na narodowość) oraz imigrantów. Kryterium „rdzenności” jest dyskusyjne; jestem skłonny uznać „rdzenność” osób, które mieszkały na Ukrainie przed rokiem 1941 oraz ich potomków, za imigrantów zaś osiedlających się na Ukrainie w latach 1944-1990 oraz ich potomków. Migracje wewnętrzne były stymulowane przez władze sowieckie, dążące do budowy jednolitego społeczeństwa (narodu-ludu ${ }^{16}$ ) sowieckiego. Jednym

13 Zagadnienie roli zachodniej kultury popularnej w procesie dekomunizacji Ukrainy zarysowałem wstępnie w artykule Droga do Majdanu. Uwagi o pewnych aspektach przemian społecznych na Ukrainie (Olszański 2007, s. 145-159).

${ }^{14}$ Larp, częściej LARP, Live Action Role Playing, forma gry fabularnej rozgrywana w formie działań terenowych, pod pewnymi względami przypominających podchody, często z elementami walki na białą broń.

15 Zorganizowani kibice piłki nożnej, organizujący zbiorowe walki wręcz (tzw. ustawki). W Polsce zwani są kibolami, termin ukraiński nie ma ładunku pejoratywnego.

16 Rosyjskie (i ukraińskie) „narod” to bardziej lud niż naród w rozumieniu europejskim („nacija”). Obecnie zdarza się usłyszeć na Ukrainie, że w toku trwającej wojny „narod” prze- 
z narzędzi takiej stymulacji było zachęcanie demobilizowanych do osiedlania się w miejscu ukończenia służby. Ważniejszym był naturalny (choć też wspierany, a częściowo sterowany przez władze) napływ pracowników do szybko rozwijających się ośrodków przemysłowych. $Z$ dostępnych danych wynika, że większość imigrantów osiedlała się w obwodach południowych i wschodnich oraz na Krymie, a także w Kijowie; w pierwszym dziesięcioleciu powojennym masowa była też migracja do opustoszałych miast zachodniej Ukrainy ${ }^{17}$.

Powojennymi imigrantami byli przede wszystkim Rosjanie, ale też na przykład Białorusini, których zgodnie ze spisem powszechnym z 1989 roku było na Ukrainie 440 tys. Część z nich, zwłaszcza członkowie rodzin wojskowych, często zmieniających miejsce zamieszkania, a także rodzin etnicznie mieszanych ${ }^{18}$, uważała się za Sowietów (ludzi sowieckich), a ta identyfikacja musiała być silna, skoro badania rejestrowały na Ukrainie sowiecką identyfikację narodową co najmniej kilkanaście lat po rozpadzie Związku Sowieckiego ${ }^{19}$. Powody trwania tej identyfikacji, zdaniem obserwatorów przede wszystkim $\mathrm{w}$ pokoleniu ukształtowanym w tzw. epoce zastoju (1966-1982), a także jej istotna treść, są wyzwaniem stojącym przed ukraińską socjologią.

Oszacowanie liczby imigrantów jest nadzwyczaj trudne, jeśli w ogóle możliwe, chyba że istnieją statystyki rejestrujące szczegółowe dane o międzyregionalnych przepływach ludności ZSRS, obejmujące zarówno osiedlających się na Ukrainie, jak i opuszczających ją. Dostępne dane nie pozwalają też oszacować liczby osób, które po kilku lub nawet kilkudziesięciu latach wewnątrzsowieckiej emigracji powracały na Ukrainę lub ją opuszczały, a także liczby potomków imigrantów (tej zapewne w ogóle nie da się uchwycić inaczej niż przez szczegółową kwerendę $w$ aktach stanu cywilnego całego kraju). Jednak już przegląd jawnych życiorysów ukraińskich osób publicznych wskazuje na to, że jest to istotna część społeczeństwa.

Przytoczę tylko kilka przykładów: Wiktor Janukowycz (premier, prezydent), syn Białorusina zesłanego do Donbasu i Rosjanki spod Kurska; Nikołaj vel Mykoła Azarow (dwukrotny premier), Rosjanin z Kaługi, który osiadł w Donbasie w wieku 37 lat; Witalij Kłyczko vel Kliczko (lider partii UDAR, mer Kijowa), syn zawodowego wojskowego (etnicznego Ukraińca), urodzony w Kirgizji, a dorastający między innymi w Czechosłowacji; Rinat Achmetow (największy oligar-

kształca się w „naciju”, przy czym chodzi o powstawanie narodu politycznego, a nie - etnicznego.

17 Bliższe, choć wyrywkowe informacje na ten temat zob. Olszański 2013, s. 21.

18 Według danych spisu powszechnego z 1979 roku mieszane etnicznie małżeństwa na Ukrainie stanowiły 19,7\%, w tym w miastach 29,6\% (wobec średniej wszechzwiązkowej 13,5 i 17,5\%); zob. Kozłow 1982, s. 281. Natomiast według Bohdana Krawczenki (1997, s. 226) liczba mieszanych etnicznie małżeństw na Ukrainie wzrosła z 15\% w 1959 roku do 20\% w 1970.

19 Według Stanisława Kulczyckiego (2013, t. 3, s. 367) w badaniach z 2004 roku za obywateli ZSRS uznało się 5,3\% Ukraińców ukraińskojęzycznych, 16,6\% Ukraińców rosyjskojęzycznych i $22,4 \%$ ukraińskich Rosjan. 
cha na Ukrainie), syn imigrantów z Powołża, do niedawna deklarujący narodowość tatarska; Jurij Jechanurow (dwukrotny premier), syn Buriata i Ukrainki (według niektórych źródeł Polki), urodzony w Jakucji, osiadły na Ukrainie w latach szkolnych, uważający się za Buriata; Siergiej vel Serhij Kunicyn (swego czasu czołowy proukraiński polityk krymski), Rosjanin urodzony w Turkmenii, osiadły na Ukrainie w latach szkolnych.

Wszystkie znane mi zarysy najnowszej historii Ukrainy wspominają o powojennej imigracji, głównie tej z pierwszego dziesięciolecia, bagatelizują jednak jej znaczenie, sugerując, że rozwój gospodarki Ukrainy następował głównie dzięki drenażowi własnej wsi ${ }^{20}$. Widać wyraźnie, że kwestia ta nie jest dostatecznie zbadana, a także - że jest to temat cokolwiek niewygodny, nie wpisujący się $\mathrm{w}$ oficjalną narrację, skoncentrowaną na rusyfikacji/denacjonalizacji Ukraińców. Nie wiemy więc, ilu może być tak definiowanych imigrantów. Na pewno wiele milionów, może nawet około jednej czwartej ludności, jak na Łotwie i w Estonii. W Zagłębiu Donieckim jest to z pewnością ponad 50\%, na Krymie przytłaczająca większość ludności słowiańskiej.

Dla tych imigrantów Ukraina nie była (i wciąż nie jest) ojczyzną, a tym bardziej - Ojczyzną ${ }^{21}$. Ich językiem ojczystym (także w symboliczno-historycznym rozumieniu) nie jest ukraiński. Podobnie dla ich dzieci i wnuków, zwłaszcza wychowanych jeszcze w czasach sowieckich. Jeśli mają oni identyfikować się nie $z$ krajem (stronami) swego pochodzenia lub Związkiem Sowieckim, muszą dokonać świadomego wyboru. Dlaczego jednak nie mieliby pozostać przy wielkomiejskiej sowieckości/tutejszości, w której wyrośli i która, generalnie rzecz biorąc, im odpowiadała?

20 Zob. np. podręcznik akademicki Nowitnia istorija Ukrajiny (Slusarenko, Husew, Łytwyn 2002, s. 490-493), gdzie czytamy, że Ukraina należała do regionów z dodatnim saldem migracji, ale główny udział we wzroście liczby mieszkańców przypisuje się przyrostowi naturalnemu (a jednocześnie - że to imigranci byli głównym jego źródłem). Autor tej części podręcznika Stanisław Kulczycki zwraca uwagę na wpływ polityki migracyjnej państwa sowieckiego na wzrost odsetka Rosjan na Ukrainie oraz na „sztuczne ukierunkowanie procesów migracyjnych na Naddnieprze”, ale nie próbuje oszacować liczebności migrantów. Niemal dokładnie te same sformułowania powtarza on w swym zarysie najnowszych dziejów Ukrainy (Kulczycki 2013, s. 262-266). Także Hiroaki Kuromiya w swej fundamentalnej pracy Swoboda i teror u Donbasi. Ukrajinśko-rosijśke prykordonnia, 1870-1990-i roki (2002) uznaje masowość powojennych migracji (np. s. 461), ale nie próbuje nawet oddzielić składowej wewnątrzrepublikańskiej od pozarepublikańskiej. Z kolei Krawczenko (1997, s. 224 i 225) pisze najpierw, że w latach 1959-1970 na Ukrainę przybyło około miliona osób, a potem - że tylko w latach 1968-1970 osiedliło się na Ukrainie 600 tys. imigrantów, w tym 428 tys. $z$ Rosji. Ten autor przynajmniej dostrzega, że migracje nie były wyłącznie efektem polityki państwa sowieckiego, lecz miały też naturalne przyczyny (Krawczenko 1997, s. 225).

${ }^{21}$ Rosyjski, a za nim ukraiński, odróżnia „rodinu” i „otiecziestwo/batkiwszczinu”; polski ma tylko „ojczyznę”. Tymczasem różnica między „ojczyzną”, związaną raczej z krajem, ziemia, pochodzeniem (ale różnym od tzw. małej ojczyzny, stron rodzinnych w ścisłym znaczeniu), a „Ojczyzną”, związaną przede wszystkim ze sferą symboliczną i państwem (istniejącym lub postulowanym), jest istotna, nie tylko w powyższym kontekście. 
Posłużyłem się tu z braku lepszego terminem, którym często określali się (lub byli określani) włościanie nie mający wyraźnej świadomości narodowej, poczuwający się do więzi lokalnej i wyznaniowej oraz do posłuszeństwa panującemu (państwu), zazwyczaj nie rozumiejący przynależności etnicznej jako „zasady tożsamości”. Zjawisko tutejszości zanikało wraz z rozwojem kulturalnym wsi, ale odnotowywano je jeszcze w II Rzeczypospolitej. Moim zdaniem, wśród robotników i niższych warstw pracowników umysłowych Związku Sowieckiego tym łatwiej postępowało rozmycie świadomości narodowej, że znaczna część społeczeństw Imperium Rosyjskiego około roku 1910 nie miała ukształtowanej takiej świadomości. Władze sowieckie starały się kształtować tożsamość sowiecką jako nie „narodową”, lecz „imperialną”, to jest skupioną wokół wierności państwu/panującemu (polegającej bardziej na posłuszeństwie niż świadomie przeżywanej więzi, którą zwykliśmy zwać wiernościa) oraz opartą na więzi ideologicznej o formach pozwalających traktować ją jako quasi-religijną. Sprzyjały też one więziom lokalnym (także $\mathrm{w}$ formie nieformalnych „ziomkostw”, powiązań wychodźców z tych samych regionów, zwłaszcza miast), ale nie - rozwojowi kultury i tożsamości etniczno-narodowej, nawet rosyjskiej. Efektem była tożsamość pod wielu względami analogiczna do dawnej „tutejszości”.

$\mathrm{Na}$ to pytanie powinien był po roku 1991 odpowiedzieć Kijów, przedstawiając imigrantom ofertę umożliwiającą im świadomy akces do narodu ukraińskiego (politycznego narodu-ludu). Nie uczynił tego nawet wobec mieszkańców Krymu. Przeszkodziło temu ignorowanie imigracyjnego charakteru znacznej części społeczeństwa, a także generalna niechęć kijowskiej biurokracji politycznej do podejmowania wyzwań związanych z "dekomunizacją” życia społecznego. Potencjał poparcia dla niepodległości ze strony górników Donbasu został zmarnowany; może nawet - nie został dostrzeżony jako cenny dla państwa ${ }^{22}$. Natomiast proukraińskie ruchy społeczne promowały derusyfikację, pozostając w kręgu tradycyjnych pojęć o języku jako esencji ukraińskiej tożsamości narodowej, a co gorsza - często utożsamiając posługiwanie się językiem rosyjskim z sowieckością.

Nie chodziło tu tylko o język i (deklarowaną lub nie) narodowość. Niechęć do mieszkańców Donbasu (w znacznie mniejszym stopniu — innych regionów wschodnich) zarówno ze strony elit, jak i — na niższym poziomie refleksji biurokratów, dużej części nauczycielstwa oraz proletariatu biurowego ${ }^{23}$ była nie tyle niechęcią do ludzi sowieckich (sowków) czy „Moskali”, ile do ludzi ciężkiej pracy fizycznej (proli, proletów) ${ }^{24}$. To także nie jest zjawisko swoiście ukraińskie. Być może elementem tej niechęci (czasem wręcz pogardy)

${ }^{22} \mathrm{Na}$ temat roli Donbasu w zdobyciu przez Ukrainę niepodległości zob. Wittkowski 1998, s. 23-57.

23 Tak wypada określić pracowników wykonujących pracę umysłową nie wymagającą wysiłku intelektualnego i ujętą $\mathrm{w}$ ścisłe procedury, zbliżone do procedur technologicznych $\mathrm{w}$ produkcji fabrycznej.

$24 \mathrm{Na}$ ten temat zob. Olszański 2014, s. 17-18. 
było odreagowywanie sowieckiego kultu pracy fizycznej (zwłaszcza górniczej i hutniczej). Wśród elit na negatywny stosunek do Donbasu miał też wpływ neoliberalny pogląd o braku perspektyw ukraińskiego przemysłu ciężkiego, zwłaszcza surowcowego ${ }^{25}$. Rozpowszechnione było też przekonanie o „kryminalnym charakterze" społeczeństwa Donbasu, pogardliwe, a krzywdzące.

To ostatnie zasługuje na bliższe naświetlenie. Utożsamianie mieszkańców Donbasu z kryminalistami, spotkane i w polskiej publicystyce, zrodziło się chyba w 2004 roku, gdy w kampanii wyborczej bardzo mocno akcentowano (i wyolbrzymiano) kryminalną przeszłość Janukowycza. To prawda, że Donbas (podobnie jak inne szybko rozwijające się ośrodki przemysłowe, nie tylko sowieckie) przyciągał przestępców zwalnianych z więzień lub uciekających przed odpowiedzialnością. Na tej samej zasadzie (można było znaleźć pracę, nie mając „czystych” dokumentów) przyciągał on jednak także byłych łagierników, którzy z punktu widzenia praworządnego państwa przestępcami nie byli, ludzi uciekających przed represjami (między innymi związanych z ukraińskim i bałtyckimi ruchami niepodległościowymi), a także przed zobowiązaniami rodzinnymi, infamią lokalnej społeczności itd. Przede wszystkim zaś - kołchozową młodzież, której przenoszenie się do miast było reglamentowane, a często sztucznie hamowane ${ }^{26}$. To wczorajsi chłopi, a nie złodzieje budowali Donbas, pokolenie za pokoleniem.

Donbas w porównaniu do innych ośrodków przemysłowych Ukrainy był zaniedbany socjalnie, silniej dotknięty bezrobociem (które zawsze jest czynnikiem kryminogennym). Miał też poczucie obcości w kraju. Sprzyjała temu słaba znajomość Ukrainy: według niektórych autorów około roku 2010 ponad jedna trzecia mieszkańców obwodów wschodnich nigdy nie była na zachodzie kraju, blisko $40 \%$ mieszkańców obwodów zachodnich nigdy nie było na wschodzie. Oznacza to, że na zachodzie własnego kraju nigdy nie była ponad połowa mieszkańców Donbasu. Ilu z nich nigdy nie było w stołecznym Kijowie, możemy się tylko domyślać.

Wreszcie Donbas nie dorobił się lokalnych elit, reprezentujących jego interesy w stolicy (znów — podobnie jak większość ukraińskich regionów). Oligarchowie w rodzaju Achmetowa koncentrowali się na własnych interesach, w regionie wznosili pomniki swojej chwały (biurowce-pałace, stadiony, niekiedy cerkwie), ale nie byli skłonni inwestować w infrastrukturę, oświatę itp.

Wszystko to umacniało alienację imigrantów, zwłaszcza, ale nie wyłącznie donieckich (oprócz najmłodszego pokolenia, dojrzewającego już w niepodległym kraju). Gdy zaś po roku 2004 Moskwa dostrzegła możliwość oddziaływania na Ukrainę kanałami „pozapolitycznymi” i zaczęła aktywnie stymulować

\footnotetext{
25 To, w jakiej mierze ten przemysł obciążał, w jakiej zaś podtrzymywał gospodarkę Ukrainy (co jest przedmiotem sporów), nie ma znaczenia dla tych rozważań.

26 Problem legalizacji takiej „imigrantki wewnętrznej” jest jednym z wątków słynnej swego czasu powieści Ołesia Honczara Sobór, której akcja rozgrywa się w Dniepropietrowsku.
} 
środowiska niechętnie nastawione do państwa ukraińskiego, na Ukrainie pojawił się nowy nacjonalizm rosyjski, wrogi ukraińskiej (w tej optyce „banderowskiej”) tożsamości narodowej. Jego przedstawiciele nie są zbyt liczni, ale są nastrojeni radykalnie, mogą więc wywierać na życie społeczne nieproporcjonalnie wielki wpływ. Część adherentów tego nurtu to członkowie najmłodszego pokolenia (wspomnianych wyżej „urodzonych obywateli”), świadomie odrzucający ukraińską narrację tożsamości, a nawet — otwarcie wrodzy państwu. Te środowiska pozostaną częścią społeczeństwa Ukrainy, niezależnie do tego, jak zakończy się obecny konflikt.

Warszawa, styczeń-kwiecień 2015

\section{BIBLIOGRAFIA}

Artur Bracki, 2009, Surżyk. Historia i teraźniejszość, Wydawnictwo Uniwersytetu Gdańskiego, Gdańsk.

Hrycak Jarosław, 2014, Rewolucija cinnostej (http://life.pravda.com.ua/society/2014/11/7/183467). Jabłonowskij Dmytro, 2014, Lisz' by nie byto wojny (www.pravda.com.ua/rus/columns/2014/05/4/ 7024316).

Kozłow W. I., 1982, Nacionalnosti SSSR. Etnodiemograficzieskij obzor, Finansy i statistika, Moskwa.

Krawczenko Bohdan, 1997, Socialni zminy i nacionalna swidomost' $w$ Ukrajini XX stolittia, Osnowy, Kyjiw.

Kulczycki Stanisław, 2013, Czerwonyj wyktyk. Istorija komunizmu w Ukrajini wid joho narodżennia do zahybeli, Tempora, Kyjiw.

Kuromiya Hiroaki, 2002, Swoboda i teror u Donbasi. Ukrajinśko-rosijśke prykordonnia, 1870-1990-i roki, Osnowy, Kyjiw.

Olszański Tadeusz A., 2007, Droga do Majdanu. Uwagi i pewnych aspektach przemian społecznych na Ukrainie, w: Jacek Borkowicz, Jacek Cichocki, Katarzyna Pełczyńska-Nałęcz (red.), Okręt Koszykowa, Wydawnictwo Naukowe PWN, Warszawa.

Olszański Tadeusz A., 2013, Kresy zachodnie. Miejsce Galicji Wschodniej i Wotynia w państwie ukraińskim, OSW, Warszawa.

Olszański Tadeusz A., 2014, Więcej jedności niż podziatów, Punkt Widzenia OSW, nr 40 (www.osw. waw.pl/publikacje/punkt-widzenia/2014-03-07/wiecej-jednosci-niz-podzialow-zroznicowani a-wewnetrzne-ukrainy).

Slusarenko A. H., Husew W. I., Łytwyn W. M., 2002, Nowitnia istorija Ukrajiny. Pidrucznyk, Wyszcza Szkoła, Kyjiw.

Wittkowski Andreas, 1998, Piatiletka biez płana. Ukraina: 1991-1996, Kyjiw.

\section{WHAT THE REVOLUTION OF DIGNITY REVEALED}

Summary

The author shows that the 2014 Revolution of Dignity brought not only revolutionary political and social changes, but also revealed the consequences of processes that had begun earlier. Society has a largely post-migration nature, shaped as a result of the resettling of people from various republics within the borders of the USSR in the years 
1944-1991. The author believes that the state's identity policy after 1991 was inconsistent on the one hand, and on the other, was based primarily on the ethnic (linguistic) concept of the Ukrainian nation. In effect, the state did not create an attractive prospect of allegiance to the nation for its inhabitants originating from Russian-speaking immigration communities, but rather the opposite-it furthered their alienation. These errors of the authorities were one of the sources of the opposition of the people of the Crimea and Donbass in 2014 in regard to the country's post-revolutionary authorities. The author nevertheless notices an important change in identification in Ukraine, occurring systematically after 1991 and connected with the growing to adulthood of a young generation educated under the influence of the national narrative in school. In the author's opinion, this determined the victory of the Revolution of Dignity.

\section{Key words/słowa kluczowe}

migrations to Ukraine in the USSR / migracje na Ukrainę w ZSRR; integration policy of Ukraine / polityka integracyjna Ukrainy; political violence during the Dignity Revolution / przemoc polityczna w czasie Rewolucji Godności 